\title{
Detecting and Analyzing Urban Regions with High Impact of Weather Change on Transport
}

\author{
S.Sangeetha, C.Anuradha,N.Priya
}

\begin{abstract}
In this report we essentially have an eye on two of the most significant inquiry that are essential for the urban region organizer to be inquired. The primary inquiry is how we can distinguish the provincial climate traffic affectability list generally the city that will surrender a thought that to how much the district traffic is affected by climate. The second inquiry is among the complex local highlights which incorporates street structures, traffic, and so on. For this we need two primary segments initially is climate traffic record foundation and key factor examination.
\end{abstract}

Keywords: traffic, weather, analysis

\section{INTRODUCTION}

Urban computing consolidate or connect information detecting, information the executives and numerous more thing. The primary objective of this venture is to take care of the different issue that happen in urban territories like contamination, traffic, vitality with the assistance of information in regards to this issue and with the assistance of human versatility and furthermore with topographical database. How about we take a guide to clarify it all the more unmistakably if there is a substantial downpour in urban territory and because of water log, there happens a traffic blockage[1]. Enormous information is a term that portrays the huge volume of information - both organized and Unstructured - that immerses a business on an everyday premise. In any case, it's not the measure of information that is significant. It's what associations do with the information that issues. Huge information can be dissected for bits of knowledge[2] that lead to better choices and key business moves. The significance of have, yet what you do with it. You can take information from any source and break down it to discover answers that empower 1) cost decreases, 2) time decreases, 3) new item improvement and enhanced contributions, and 4) savvy basic leadership.[10,11,12]

Revised Manuscript Received on July 22, 2019.

S.Sangeetha, Department of Computer Science and Engineering, Bharath Institute of Higher education and research, Chennai , India.Email: sangeethasathya01@gmail.com

C.Anuradha Department of Computer Science and Engineering, Bharath Institute of Higher education and research, Chennai , India.Email: anuradha.ak23@gmail.com

N.Priya, Department of Computer Science and Engineering, Bharath Institute of Higher education and research, Chennai, India. Email:priyabiher@gmail.com

\section{EXISTING WORK}

The creator H.S. Mohana built up another methodology in identifying and countingvehicles in day condition by utilizing ongoing traffic transition through differential procedures. Tallying object pixel and foundation pixel in an edge prompts the traffic motion estimation. The fundamental thought utilized is variety in the rush hour gridlock transition thickness because of essence of vehicle in the scene. In this paper a straightforward differential calculation is structured and tried with vehicle discovery and checking application. Traffic transition estimation will assume indispensable job in actualizing vehicle recognition and checking plan. Ongoing powerful scene examination has turned out to be significant perspective as the expansion in video investigation. The strategy created is havingstraightforward measurable foundation. Dynamic choice of pictures from the grouping is executed effectively so as to decrease the calculation time. The planned method are assessed such a 20 distinctive video arrangements and weighed completely with straightforward certainty measures.[40,41] To make the plan enlightenment invariant, a segment of the foundation is taken as reference, which won't be influenced by the traffic stream. Edge is fixed and used to segregate the low, medium and high traffic transition. There is a plot for traffic transition thickness; it's essentially $1 \%$ motion thickness versus number of casings. Fundamentally vehicle discovery is done by utilizing this plot. Assume on the off chance that there is vehicle in the scene, at that point there is a transition change as per vehicle estimate. Clearly whether there is enormous vehicle (or article), there is greatest or if there is little vehicle(or object), there is least measure of transition (white pixels). [13,14,15] Laura Munoz proposed a framework to gauge traffic thickness with the cell transmission model. This uses cell densities as state factors rather than cell inhabitances, and furthermore acknowledges non uniform cell lengths, and enables clogged condition to be kept up at the downstream limit of a demonstrated road area. Utilizing cell densities rather than cell inhabitances licenses to incorporate uneven cell lengths, which prompts more prominent adaptability in parceling the expressway. [16,17,18]

Tomas Rodriguez proposed a framework on ongoing traffic checking; the framework is self-versatile and can work independently for extensive stretches of time, for example no concealed parameters to be balanced. It performs altogether climate condition and consequently chooses the proper calculation for day, night and progress periods. The framework is hearty against 
quick and moderate enlightenment changes and can adapt to long broken shadows, and shadows from parallel roadways. Standard camera developments (for example wind vibrations) scarcely influence its exhibition in light of the fact that the framework is tolerant against fleeting following blunders and exacting requirements are utilized to distinguish the vehicles. They additionally give a sufficient treatment of impediments and overwhelming vehicles, and got sensible outcomes in thick rush hour gridlock. A comprehensive investigation of the operational condition; a compelling adjustment and picture amendment strategy; a unique division approach, supplemented with a creative technique for the programmed determination of the division parameters; a location and following methodology extraordinarily intended for traffic environments;67a vigorous shadow evacuation technique; explicit arrangements for substantial vehicle discovery and the treatment of impediments; lastly, semantic testing and benchmarking procedure. Here the framework fragments the video by separating the moving objects of the scene and playing out a primer grouping (for example it won't endeavor to distinguish shadows). When the work picture has been made the picture is divided by removing the moving items utilizing an adaption of understood back-ground concealment methods. The framework utilizes recognition and following strides to make a deliberation of physical items certain in the division veil for each approaching picture and afterward track those articles in the grouping until all vehicles and shadows present in the scene is recognized. [,19,20,21]

P.F Alcantarilla proposed a programmed street traffic control and observing framework for day time grouping utilizing a high contrast camera. Significant street traffic data, for example, mean speed, measurement and vehicles tallying are gotten utilizing PC vision techniques. Right off the bat, moving articles are extricated from the scene by methods for an edge differencing calculation and surface data dependent on dim scale power. Be that as it may, shadows of moving articles have a place additionally with the frontal area. Shadows are expelled from the forefront articles utilizing top cap changes and morphological administrators. At last, objects are followed in a Kalman separating procedure, and parameters, for example, position, measurements, separation and speed of moving articles are estimated. At that point, as indicated by these parameters moving items are named vehicles (trucks or autos) or disturbance antiquities. For checking vehicles, moving items must be extricated from pictures.

Frank Y. Shih proposed a framework for programmed seeded district developing calculation for shading picture division. Initially, the information RGB shading picture is changed into shading space. Second, the underlying seeds are naturally chosen. Third, the shading picture is divided into districts where every locale compares to a seed. At long last, locale blending is utilized to combine comparative or little areas. [34,35,36]

M. Vargas proposed a framework for video based traffic thickness estimation. Fruitful video-based frameworks for urban traffic observing must be versatile to various conditions. They ought to incorporate calculations for location of moving vehicles and present moment stopped vehicles (particularly significant in urban conditions). Therefore, foreground/foundation segregation or highlight following. An adjustment of sigma-delta foundation subtraction calculation has been exhibited. This adjustment attempts to keep the effortlessness and computational effectiveness of the first strategy, while giving more strength to the accomplished foundation model in run of the mill urban traffic scenes. Beginning from the fundamental sigma-delta calculation, a certainty estimation has been incorporated, considering not just the force fluctuation on every pixel yet additionally the estimation of the traffic stream over that pixel.[22,23,24]

\section{PROPOSED WORK}

Proposed idea manages giving database by utilizing Hadoop[3] instrument we can dissect no impediment of information and basic add number of machines to the group and we get results with less time, high throughput and maintence cost is extremely less and we are utilizing joins, segments and bucketing strategies in Hadoop. [37,38,39]

- Focal points

- No information misfortune issue

- Efficient information preparing.

\section{ARCHITECTURE DIAGRAM}

Framework engineering[4] can contain framework segments, this inside works as java code, that will cooperate to execute the general framework for huge information dealing with handling and cost is less.

LIST OF MODULES

- Preprocessing Database

- Data Load

- Analyze Query

- Scripting Process

- Parallel process

MODULE DIAGRAMS AND DESCRIPTION

- Preprocessing

- Weather Database:

In this module, investigating the information with various types of fields in Microsoft Excel then it changed over into comma delimited configuration which is said to be csv(comma separator esteem) record and moved to mysql reinforcement through Database[5].

Capacity : The client takes MySQL information into programming instrument by getting the information through sqoop and store in Hdfs.

Break down Query : Utilizing hive inquiry language[6] it tends to be dissected in various capacities like dividing, bucketing in organized table and produce in reassure yield as indicated by inquiries and broke down in climate change dependent on clients vehicle [25,26,27]

Scripting Process: In this module, utilizing pig scripting particularly said to be a simple apparatus where increasingly more investigative should be possible by obscure developer too. Make social table and store the information in hdfs[7] .. 


\section{RESULT AND DISCUSSION}

In this we implement the coding part using eclipse by Fig:1. Below are the coding's that are used to generate the domain module by Fig: 2 for electronic text books. Here the proposed techniques are used in the coding [8] part to generate the e-books.[28,29,30]

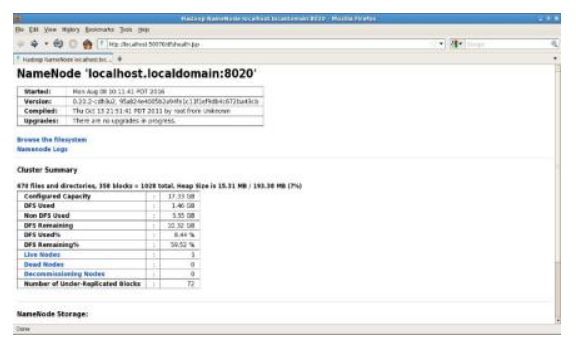

Fig:1 Data Coding
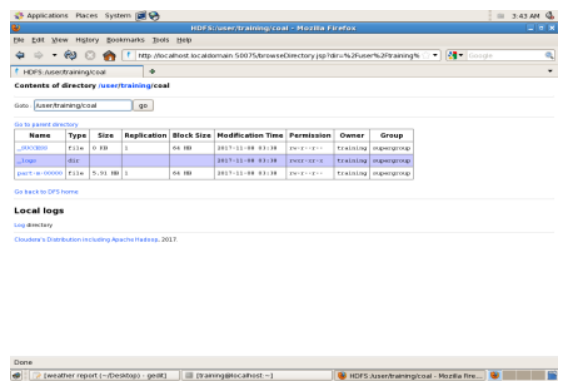

Fig:2 Domain Module

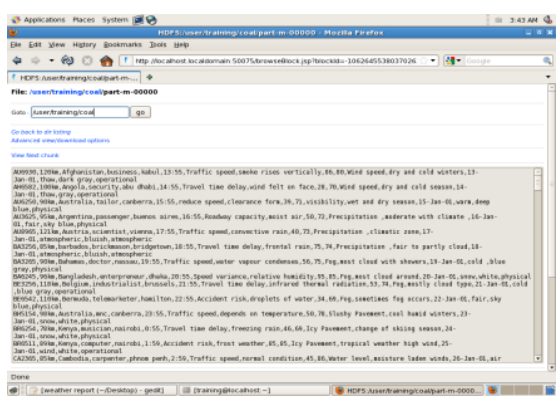

Fig:3 Impact of Weather

\section{CONCLUSION}

We introduced a climate change report by producing information reinforcement scarcely taken two years of information using Fig:3. Which can be helpful to make a trip from source to goal whether streets are collected with water or not and atmosphere shifts time-to-time. So forecast should be possible effectively, no confinement of information, minimal effort[9]. Because of progression of enormous information examination its handling velocity is quick and product equipment likewise utilized. [31,32, 33]

\section{REFERENCES}

[1] A., Rangarajan K.,Algorithm for automaton specification for exploring dynamic labyrinths,Indian Journal of Science and Technology,V-6,I-SUPPL5,PP-4554-4559,Y-2013

[2] P. Kavitha, S. Prabakaran "A Novel Hybrid Segmentation Method

with Particle Swarm Optimization and Fuzzy C-Mean Based On Partitioning the Image for Detecting Lung Cancer" International Journal of Engineering and Advanced Technology (IJEAT) ISSN: 2249-8958, Volume-8 Issue-5, June 2019

[3] Kumaravel A., Meetei O.N.,An application of non-uniform cellular automata for efficient cryptography,2013 IEEE Conference on Information and Communication Technologies, ICT 2013,V-,I-,PP-1200-1205,Y-2013

[4] Kumarave A., Rangarajan K.,Routing alogrithm over semi-regular tessellations,2013 IEEE Conference on Information and Communication Technologies, ICT 2013,V-,I-,PP-1180-1184,Y-2013

[5] P. Kavitha, S. Prabakaran "Designing a Feature Vector for Statistical Texture Analysis of Brain Tumor" International Journal of Engineering and Advanced Technology (IJEAT) ISSN: 2249-8958, Volume-8 Issue-5, June 2019

[6] Dutta P., Kumaravel A.,A novel approach to trust based identification of leaders in social networks,Indian Journal of Science and Technology,V-9,I-10,PP--,Y-2016

[7] Kumaravel A., Dutta P.,Application of Pca for context selection for collaborative filtering,Middle - East Journal of Scientific Research,V-20,I-1,PP-88-93,Y-2014

[8] Kumaravel A., Rangarajan K.,Constructing an automaton for exploring dynamic labyrinths,2012 International Conference on Radar, Communication and Computing, ICRCC 2012,V-,I-,PP-161-165,Y-2012

[9] P. Kavitha, S. Prabakaran "Adaptive Bilateral Filter for Multi-Resolution in Brain Tumor Recognition" International Journal of Innovative Technology and Exploring Engineering (IJITEE) ISSN: 2278-3075, Volume-8 Issue-8 June, 2019

[10] Kumaravel A.,Comparison of two multi-classification approaches for detecting network attacks, World Applied Sciences Journal,V-27,I-11,PP-1461-1465,Y-2013

[11] Tariq J., Kumaravel A.,Construction of cellular automata over hexagonal and triangular tessellations for path planning of multi-robots,2016 IEEE International Conference on Computational Intelligence and Computing Research, ICCIC 2016,V-,I-,PP--,Y-2017

[12] Sudha M., Kumaravel A.,Analysis and measurement of wave guides using poisson method,Indonesian Journal of Electrical Engineering and Computer Science,V-8,I-2,PP-546-548,Y-2017

[13] Ayyappan G., Nalini C., Kumaravel A.,Various approaches of knowledge transfer in academic social network,International Journal of Engineering and Technology,V-,I-,PP-2791-2794,Y-2017

[14] Kaliyamurthie, K.P., Sivaraman, K., Ramesh, S. Imposing patient data privacy in wireless medical sensor networks through homomorphic cryptosystems 2016, Journal of Chemical and Pharmaceutical Sciences 92.

[15] Kaliyamurthie, K.P., Balasubramanian, P.C. An approach to multi secure to historical malformed documents using integer ripple transfiguration 2016 Journal of Chemical and Pharmaceutical Sciences 92 .

[16] A.Sangeetha,C.Nalini,"Semantic Ranking based on keywords extractions in the web", International Journal of Engineering \& Technology, 7 (2.6) (2018) 290-292

[17] S.V.GayathiriDevi,C.Nalini,N.Kumar,"An efficient software verification using multi-layered software verification tool "International Journal of Engineering \& Technology, 7(2.21)2018 454-457

[18] C.Nalini,ShwtambariKharabe,"A Comparative Study On Different Techniques Used For Finger - Vein Authentication", International Journal Of Pure And Applied Mathematics, Volume 116 No. 82017 , 327-333, Issn: 1314-3395

[19] M.S. Vivekanandan and Dr. C. Rajabhushanam, "Enabling Privacy Protection and Content Assurance in Geo-Social Networks", International Journal of Innovative Research in Management, Engineering and Technology, Vol 3, Issue 4, pp. 49-55, April 2018.

[20] Dr. C. Rajabhushanam, V. Karthik, and G. Vivek, "Elasticity in Cloud Computing", International Journal of Innovative Research in Management, Engineering and Technology, Vol 3, Issue 4, pp. 104-111, April 2018.

[21] K. Rangaswamy and Dr. C. Rajabhushanamc, "CCN-Based Congestion Control Mechanism In Dynamic Networks", International Journal of Innovative Research in Management, Engineering and Technology, Vol 3, Issue 4, pp. 117-119, April 2018. 
[22] Kavitha, R., Nedunchelian, R., "Domain-specific Search engine optimization using healthcare ontology and a neural network backpropagation approach", 2017, Research Journal of Biotechnology, Special Issue 2:157-166

[23] Kavitha, G., Kavitha, R., "An analysis to improve throughput of high-power hubs in mobile ad hoc network" , 2016, Journal of Chemical and Pharmaceutical Sciences, Vol-9, Issue-2: 361-363

[24] Kavitha, G., Kavitha, R., "Dipping interference to supplement throughput in MANET" , 2016, Journal of Chemical and Pharmaceutical Sciences, Vol-9, Issue-2: 357-360

[25] Michael, G., Chandrasekar, A.,"Leader election based malicious detection and response system in MANET using mechanism design approach", Journal of Chemical and Pharmaceutical Sciences(JCPS) Volume 9 Issue 2, April - June 2016

[26] Michael, G., Chandrasekar, A.,"Modeling of detection of camouflaging worm using epidemic dynamic model and power spectral density", Journal of Chemical and Pharmaceutical Sciences(JCPS) Volume 9 Issue 2, April - June 2016.

[27] Pothumani, S., Sriram, M., Sridhar, J., Arul Selvan, G., Secure mobile agents communication on intranet,Journal of Chemical and Pharmaceutical Sciences, volume 9, Issue 3, Pg No S32-S35, 2016

[28] Pothumani, S., Sriram, M., Sridhar, Various schemes for database encryption-a survey, Journal of Chemical and Pharmaceutical Sciences, volume 9, Issue 3, Pg NoS103-S106, 2016

[29] Pothumani, S., Sriram, M., Sridhar, A novel economic framework for cloud and grid computing, Journal of Chemical and Pharmaceutical Sciences, volume 9, Issue 3, Pg No S29-S31, 2016

[30] Priya, N., Sridhar, J., Sriram, M. "Ecommerce Transaction Security Challenges and Prevention Methods- New Approach” 2016 ,Journal of Chemical and Pharmaceutical Sciences, JCPS Volume 9 Issue 3.page no:S66-S68

[31] Priya, N.,Sridhar,J.,Sriram, M."Vehicular cloud computing security issues and solutions" Journal of Chemical and Pharmaceutical Sciences(JCPS) Volume 9 Issue 2, April - June 2016

[33] Priya, N., Sridhar, J., Sriram, M. "Mobile large data storage security in cloud computing environment-a new approach" JCPS Volume 9 Issue 2. April - June 2016

[34] Anuradha.C, Khanna.V, "Improving network performance and security in WSN using decentralized hypothesis testing "Journal of Chemical and Pharmaceutical Sciences(JCPS) Volume 9 Issue 2, April - June 2016.

[35] Anuradha.C, Khanna.V, "A novel gsm based control for e-devices" Journal of Chemical and Pharmaceutical Sciences(JCPS) Volume 9 Issue 2, April - June 2016 .

[36] Anuradha.C, Khanna.V, "Secured privacy preserving sharing and data integration in mobile web environments " Journal of Chemical and Pharmaceutical Sciences(JCPS) Volume 9 Issue 2, April - June 2016.

[37] Sundarraj, B., Kaliyamurthie, K.P. Social network analysis for decisive the ultimate classification from the ensemble to boost accuracy rates 2016 International Journal of Pharmacy and Technology 8

[38] Sundarraj, B., Kaliyamurthie, K.P. A content-based spam filtering approach victimisation artificial neural networks 2016 International Journal of Pharmacy and Technology 83 .

[39] Sundarraj, B., Kaliyamurthie, K.P. Remote sensing imaging for satellite image segmentation 2016 International Journal of Pharmacy and Technology 83.

[40] Sivaraman, K., Senthil, M. Intuitive driver proxy control using artificial intelligence 2016 International Journal of Pharmacy and Technology $8 \quad 4$.

[41] Sivaraman, K., Kaliyamurthie, K.P. Cloud computing in mobile technology 2016 Journal of Chemical and Pharmaceutical Sciences 92.

[42] Sivaraman, K., Khanna, V. Implementation of an extension for browser to detect vulnerable elements on web pages and avoid click jacking 2016 Journal of Chemical and Pharmaceutical Sciences 92.

\section{AUTHORS PROFILE}

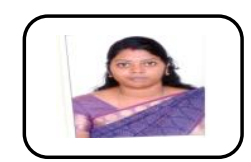

S.Sangeetha, Assistant Professor, Department of Computer Science \& Engineering, Bharath Institute of Higher Education and Research, Chennai, India

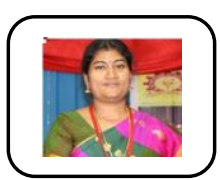

C.Anuradha, Assistant Professor, Department of Computer Science \& Engineering, Bharath Institute of Higher Education and Research, Chennai, India

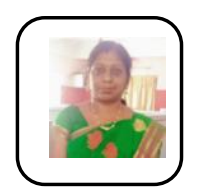

N.Priya, Assistant Professor, Department of Computer Science \& Engineering, Bharath Institute of Higher Education and Research, Chennai, India 